\title{
The Enlightenment of Students' Growth from Young Mao's Self-realization
}

\author{
Liu Jie
}

Number 18 of Tian Xin Street, Zhuzhou City, Hunan Province, China

Liujie8782@163.com

Keywords. Young Mao Zedong; Self-actualization theory; College students

\begin{abstract}
The article studies young Mao Zedong's theory of self-realization, including the outlooks on the life, values and practice, analyzes the profound effect on Mao's lifetime activities tend and the trajectories of thought development had by his theory of self-realization, and points out that the college students are important national human resources, who are in a critical period of developments of the outlooks on the life, world and values. In the face of such social reality as the profound social transformation, increasingly diverse ideas and continuously technology change, to study young Mao' self-realization in depth is instructive for the growth of contemporary college students.
\end{abstract}

\section{Introduction}

College students are the valuable human resources, the hope of the nation, and the future of the country. Most contemporary college students are 90s, generally the only child, and have strong self-consciousness. They are eager to become the future pillars of the society and realize their life values. But how to realize their dream and become the future pillars of the country are a confusing issue for some students and also a issue that college students want to discuss. Young Mao Zedong's theory of self-realization is the outlooks on the life, values and practice in the period of Mao's youth. We understand it, take advantage of it and enforce pointed ideological and moral education on college students, which may have certain significance for shaping the personality of contemporary, forming the correct values and solving the puzzles of becoming a useful person.

\section{The noble life ideal that "One regards the whole society as one's own duty"}

In contemporary some college students' value orientations are too utilitarian, and lack of lofty ideals and lofty aspirations. Some students think that learning is just to get a diploma and then find a satisfactory job. Some students do not have any more ideas, and goof in college period. There are also some students obsessed by the ideas of staying in the big cities, or asking for good jobs after graduation. Their eyes only fix on the personal gains, but do not realize that "Home come after the country".

In order to save the disaster-ridden country, explore the truth of salvaging country and national, young Mao Zedong joined in Hunan First Normal established in 1914. He continued to study was driven by a powerful intrinsic motivation, which means that the fate of the nation is everyone's responsibility. He named himself as "zi ren" to encourage himself. Young Mao Zedong wrote in the "lecture recorded" that "Making an ideal, and then all of a dynamic fit this ideal". He has always taken lofty ideals and aspirations as a fundamental source of strength and moral life. With a "self-realization" ideal taken and the rise and fall of the country shouldered, the young Mao Zedong studied hard. Every day, he got up early and started the morning with reading; later in the evening, when everybody went to bed, he often read in the stove room or the hallway lighting. Mao Zedong not only widely read foreign and domestic books of humanities and Social Sciences, do his best to make progress, but also actively engaged in social practice, understood the social, and concerned about national affairs. In 1915, in order to expose Yuan Shikai's activities of accepting Japan 's "21 terms" and the ultimatum, Mao Zedong wrote in "Shame articles", "May 7 , the republic humiliation; how to revenge , our students' responsibilities." Patriotism was palpable. As the young Mao Zedong's opinions, only to establish the ideal of "One regards the whole society as one's own duty ", go with 
the noble sense of social responsibility, and then work out to seek the truth of the universe, which combined together, and took actual actions, could realize one's own ideals.

From here, we can see that precisely because of the young Mao Zedong combining personal ideals and the fate of the motherland together, a powerful internal learning drive was produced for working hard and exploring new knowledge, so that a way to go for Chinese People was ultimately found. Young Mao Zedong analyzed that the so-called personal values is "the spirit of individualism", which represents a moral ideal, and a pursuit of a personality in a set of saints ideal. Its essence is the "self-realization", which let people become a moral autonomy, tranquility distress, Saint and king -like people. As a contemporary college students who shoulder the task of the Chinese nation, we should start acting now and doing it by oneself, put our own life ideals and values together with social progress and development, take the country's future and fate as one's own duties, and find the best combination between personal struggle and contribute to social development. We should consciously use what they have learned into the national modernization, voluntarily get into hard trade and go to remote areas. We can return country and society by our own actions.

\section{Being a "well-read, sincere conduct" person}

Mao Zedong's life is one pursuit of truth life. From the young age, he considered "theoretical" "isms" as the law of dong something and the fundamental that transformed China and the world. Thus, Mao Zedong showed a positive spirit of exploration on the "isms", without compromise and concessions. Those which met the "isms" were given the stick, but those which did not meet the "isms" were given criticism. No matter whether he pleased everyone in the end or not, but just considered what he had done fitting into his will and the truth or not. Mao Zedong especially emphasized combining the innate instincts with acquired knowledge that was certain theory. Under certain ideological guidance, we could establish a firm belief, form a strong will, and then put into practical actions to enable the successful realization of personal value. Mao Zedong pointed out that "Knowledge, letter, action are three steps for our spiritual activities".

Having own opinions, no blind obedience, no drifting with the current are a remarkable personality traits of young Mao Zedong. Although Yang Changji was the teacher respected by Mao, but he advocated "sit" as a good way to cultivate one's moral character and criticized Mao having a "Still" problem. Mao Zedong did not agree. On the contrary, he also wrote an article entitled "Study of Physical", specifically criticized the "tranquility" saying, and advocated "dynamic" and "please our soul and cultivate our mind". It is also very worthy of contemporary college students' study. On the scholarship, as long as some students heard an idea proposed by a teacher or authority, they would not add any analysis and consideration and are blind to meet them, completely without self- assertive. Even some have their own opinions, but also have no courage to put forward. Under such circumstances, the students' innovative consciousness will disappear.

Mao Zedong not only abide by the purpose that "anything can be sacrificed, the only purpose can not be sacrificed", and the advocates of common debate, discussion and collective research in the pursuit of "isms", but also oppose individual wrestling, advocate coalition, opposite lonely fight and take out the discusses of "Isms". And he also considers all interests ready to give way, but "the dispute of doctrine has to fight for, and that is not private individuals". In addition to the truth, we could let the others given generously to friends, which not only adhere to the principle of seeking the truth, but also don't hurt friends. This practice for us to correctly handle the relationships of today's college students really means greatly.

Young people firstly enter university, many of whom are just out of their parents' wings protection. At home, everything is swept by parents, once entering university, they find it difficult to adapt, especially the only child of the family, who do not know how to relate to other people. Some students blindly agree with others, in order to let others have no objection to themselves; some weird and eccentric loners are always on guard against others in conflict; There are some people , at work, in order not to offend , take in exchange principle. All this indicates a problem in their lifetime. If they 
do not correctly handle the relationship between themselves and the people around them, there will be adverse affect for their own talent and start work in society.

How can we handle the relationship with students around us? I think that we might study the young Mao Zedong's approach. As contemporary college students, we shoulder construction task of socialism with Chinese characteristics and strive to learn knowledge, a solid grasp of the skills, and improve their overall quality is a priority, which is also the middle of this. All interpersonal relationship problems should be solved without prejudice to this important task for the purpose. When you go the library, or someone asks you out to get on internet and play games, then you do not have to deny him embarrassed. When you stick to principles or refuse to do things detrimental to public morals, you do not feel sad because of someone else's cynical. You will be successful, if you stick right and resist wrong perseveringly, and use your own behavior to infect, lead, affect a number of students to form a good learning environment. Secondly, you have to deal with the relationship between personal interests and people's interests and collective interests correctly. Young Mao Zedong in the long-term practice of the Chinese revolution and construction to consciously turn our gaze to the masses, always put the people and the collective interests first, individual interests and collective interests of the people to obey, serve the people wholeheartedly, as contemporary youth interests and properly handle the relationship between individual and collective interests of the people provides an example, but also for the students to provide guidance in dealing with students around other relations.

\section{The strong will and active attitude towards life}

Some contemporary college students are only child, who grow up in the optimum environment, and have psychological vulnerability, bearing little hardships and wrong, have poor will, and are afraid of setbacks.

Young Mao Zedong is ambitious, strong-willed. "Confident life lasts two hundred years, and you would be splashing into the water three miles". He has early stressed that people should have strong willpower. We do not be afraid of difficulties, obstacles and setbacks, and also aren't afraid to fail, even so leading demoralized. We should dare to fight, and fight well, and have the courage to have a positive attitude towards life. To hone your willpower, young aspiring young Mao Zedong united ambitious youth in Changsha to organize camps, eating and living outside, swimming, hiking, going through wild forest. They took misery as training for the upcoming social struggle and transformation of the country. "Obviously, Mao appreciated ancient brave generals very much, who dare to struggle and fight in battle. Visibly, Mao Zedong exhibited an uplifting spirit during the study. After joining the revolution, Mao Zedong are never once discouraged by setbacks until successes.

In the process of achieving the ideal of their life, college students will certainly encounter kinds of difficulties and setbacks, and their life can not be plain sailing. Therefore, the students should strive to develop their own strong will and courage to forge ahead in the spirit, learned by the young Mao Zedong. Firstly, college students should establish a correct outlook on life under the premise and strive to develop their own sense of self-confidence and courage to overcome difficulties. People need a little spirit. Only one establishes his confidence, and drive himself in such a strong motivation and self-confidence to radiate enormous potential and achieve a good condition. Secondly, a careful analysis of their strengths and weaknesses should be done, and one kind of love for life open-minded optimism should be held. We have to learn to be ready to start from little things, earnest read and solidly cultivate their quality and ability to constantly improve ourselves.

\section{"Exercising physique", being a perfect person}

If you want to realize yourself and both body and mind develop well, the first thing is to develop body and strengthen bones and muscles. This is another point that the theory of self-realization of young Mao Zedong emphasized. Of course, the intellectual and moral is very 
important, even fundamental reason why people sign people and ethnic newborn. But the young Mao Zedong reminder that the most important prerequisite for a more easy to forget that support intellectual, practice what moral carrier is undoubtedly the body and stamina. "Bodies are the loader of knowledge and moral virtues". "No morality and intelligence exits without bodies". Originally, people pursue their own ideals, if they work hard, there will be fruit any way. But "people are afraid of no bodies". Because only strengthen their bodies, they can improve themselves and then "brave and effective moral education goes far". Otherwise, emphasizing the importance of intellect and morality is just an empty word. "Once a body does not exist, intellect and morality also disappears". Mao Zedong believed the fate of countless heroes in history have confirmed this basic truth. Yan Yuan, Jia Yi , Wang Bo, Lu Zhaolin , etc. , are all the people who have higher levels of intellect and morality but do not pay attention physique practice. They are all frail scholar, who are eventually "short-lived", or "early-died", or" baby-hurt" or "seat-depended". Instead, whom Mao Zedong yearned and respected are those martial sages, brave warrior strong, free and easy swordsman. Thus, he advocated the acting styles of practical school whose representatives are Yan Xizhai, Li Gang.

How can we balance the development of moral, intellectual and physical education? Moral education must be taken out through teachers' words, deeds and personal accomplishment. Moral education trains student being sound in responsibility and obligation, and developing a progressive outlook on life struggle. Intellectual education is "knowledge storage". Students increase their knowledge and talents through reading and study. As for physical education, it's to strength students' bodies, maintain long-term vitality, and ultimately achieve the highest regard to physical ability through many kinds of sports. In young Mao Zedong's opinions, if those kinds of education are put into effect together, college students would train themselves into a pillar of the country.

Some of the college students really pay much attention to their studies, but they ignore a truth that body is the capital of revolution. They usually just blindly hit the books and never participate in any physical exercise. Therefore, the number of obese students, eye-wearing students, poor physical quality students is becoming more and more. We have to know that current talent competition is a fully integrated competition. If you had a strong knowledge of light without a qualified healthy body, it would be difficult to win in the future competition. Secondly, physical exercise cultivates not only human's spirit but also the noble personality. Therefore, the contemporary college students should take more proactive part in physical exercise, in order to improve their physical fitness and develop a variety of good will.

\section{Acknowledgements}

This work was financially supported by the Zhuzhou Society and Science Foundation (ZZSK14114).

\section{References}

[1] Mao Zedong early presentation of [M]. Changsha: Hunan publishing , 1995

[2] Mo Zhibin. Mao Zedong Thought of modern Hunan Youth: politicians thought research [M]. Changsha: Hunan Normal University press, 2003.

[3] Li Yinqiao down the aisle of Mao Zedong [M]. Beijing: Chinese and foreign cultural publishing company, 1989

[4] Li Chunqiu [J]. Journal of Beijing Normal University, view of value of life youth Mao Zedong 1993, (6): 44-46

[5] Gao Denghui and its significance [J]. Jiamusi University social science view of life value, Mao Zedong young 2000, (6): 103-105 